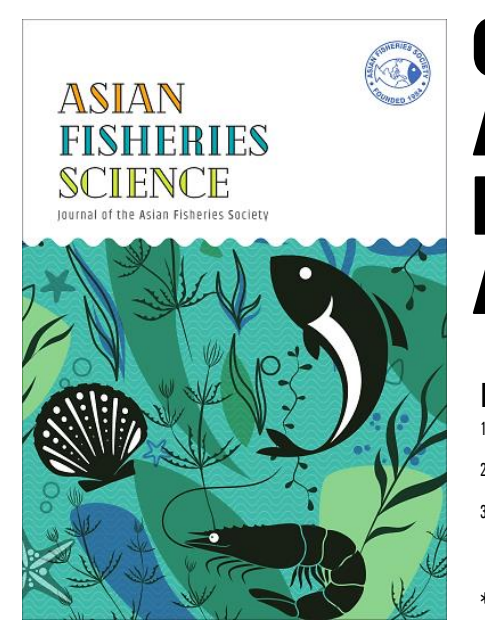

\title{
Guidance in Development of Aquaculture Component of a National Action Plan on Antimicrobial Resistance
}

\author{
MELBA G. BONDAD-REANTASO ${ }^{1, *}$, CELIA LAVILLA-PITOGO² ${ }^{2}$ MA. MICHELLE L. LOPEZ ${ }^{3}$, BIN HAO ${ }^{1}$ \\ 'Fisheries Division, Food and Agriculture Organization of the United Nations (FAO), Rome, Italy \\ ${ }^{2}$ Tigbauan 5021, lloilo, Philippines \\ ${ }^{3}$ Department of Food Technology, University of Santo Tomas, Manila, Philippines
}

*E-mail: Melba.Reantaso@fao.org

(C)Asian Fisheries Society

ISSN: 0116-6514

E-ISSN: 2073-3720

https://doi.org/10.33997/j.afs.2020.33.S1.017

\begin{abstract}
Since the adoption, in May 2015, of the Global Plan of Action (GAP) on Antimicrobial Resistance (AMR), during the 68th World Health Assembly of the World Health Organization (WHO) and the subsequent adoption by the delegates of the World Organisation for Animal Health (OIE) of the OIE AMR Strategy and the adoption of Resolution 4/2015 by the 39th Conference of the Food and Agriculture Organization of the United Nations (FAO), a political declaration was made during a high-level meeting on AMR at the 71st United Nations General Assembly (UNGA, September 2016). The UNGA called upon the Tripartite (i.e. WHO, OIE, and FAO) and other intergovernmental organisations to support the development and implementation of National Action Plans (NAPs) and AMR activities at the national, regional, and global levels under the One Health platform. This paper provides preliminary guidance in the development of the aquaculture component of NAP on AMR under the auspices of the FAO project FMM/RAS/298/MUL: Strengthening capacities, policies, and national action plans on prudent and responsible use of antimicrobials in fisheries. Such guidance, consisting of two levels (i.e. generic and aquaculture-specific), are important first steps in the process. Having such a plan will now allow the responsible Competent Authority to raise the profile of aquaculture in national discourses on AMR, generate an understanding of the sector and its importance by other relevant sectors engaged in the One Health platform, stimulate investment and support towards further development and implementation of the action plan. The aquaculture component needs to be fully integrated in a country's NAP on AMR.
\end{abstract}

Keywords: NAP, AMR, One Health

\section{Introduction}

Antimicrobial resistance (AMR) is a global concern and is now recognised as one of the greatest threats to public health worldwide. In order to address the crisis brought about by systematic misuse and overuse of antimicrobial drugs that contributed to the emergence and spread of antimicrobial-resistant organisms and that threatens the sustainability of an effective, global public health response to risks of infectious diseases, in May 2015, the Global Plan of Action on AMR (GAP) was adopted during the 68th World Health Assembly of the World Health Organization (WHO). The World Organisation for Animal Health (OIE) and the Food and Agriculture Organization of the United Nations (FAO) contributed to the GAP. The OIE delegates, in May 2015, adopted the OIE AMR strategy (OIE, 2016), and the 39th FAO Conference (June 2015) adopted Resolution 4/2015 to support the GAP (FAO, 2016). A political declaration was made during a high-level meeting on AMR at the 71st United Nations General Assembly (UNGA, September 2016) (WHO, 2015) which called upon the Tripartite (i.e. FAO as the global leader for food and agriculture, the OIE as the global leader for animal health and welfare, and WHO as the global leader for human health) and other intergovernmental organisations to support the development and implementation of National Action Plans (NAPs) and AMR activities at the national, regional and global levels under the One Health platform.

In 2017, the FAO implemented a project FMM/RAS/298/MUL: Strengthening capacities, policies, and national action plans on the prudent and 
responsible use of antimicrobials in fisheries. The objectives of this project were to develop and/or enhance the knowledge, skills, and capacity of the participating Competent Authorities (CA) on fisheries and aquaculture, as well as to assist the CAs in the development and implementation of policies and national action plans (NAPS) on the prudent and responsible use of antimicrobials (FAO, 2017; BondadReantaso et al., 2020).

This paper provides preliminary guidance in the development of the aquaculture component of NAP on AMR under the auspices of the above mentioned FAO project FMM/RAS/298/MUL. Two levels of guidance were provided: (i) generic guidance and (ii) specific guidance in aquaculture.

\section{Guidance in the Development of the Aquaculture Component of National Actions Plans (NAPs) on Antimicrobial Resistance (AMR)}

The guidance involves two levels, i.e., generic and aquaculture-specific.

1. Generic guidance. The first generic step is to review the WHO Global Plan of Action and the subsequent plans of actions of OIE and the FAO (Table 1). These action plans can guide countries in the development of their national action plans and determine what objectives or pillars of a country action plan may be appropriate. A country's AMR NAP is usually led and coordinated by the relevant health ministry.
2. Aquaculture-specific guidance. The next step is to understand the aquaculture sector and examine different aspects and how they may relate to the emergence of AMR in aquaculture. The following actions are recommended:

a) Review/prioritisation of the most important cultured species based on production statistics;

b) Review/prioritisation of the most important bacterial diseases (Table 1) affecting the most important cultured species based on agreed criteria;

c) Review Codex Alimentarius maximum residue limit (MRL);

d) Collect information on actions to deal with bacterial diseases (prevention, good aquaculture/biosecurity practices, treatment with antibiotics, alternative treatment, and other measures);

e) Provide guidance on the mechanisms for collection of information on AMU and AMR surveillance; and

f) Identify requirements for $A M U$ and $A M R$ surveillance (such as personnel, field/laboratory procedures, skills, facilities, policies/legislation, keeping, monitoring).

reporting/record

For 2a, most aquaculture-producing countries have national aquaculture production statistics and aquaculture action plans and/or aquaculture policy documents which may provide information on priority aquaculture species; these can be a very useful source of data.

Table 1. Objectives of the action plans on AMR of the World Health Organization, the World Organisation for Animal Health, and the Food and Agriculture Organization of the United Nations.

\begin{tabular}{lll}
\hline $\begin{array}{l}\text { World Health Organization } \\
\text { (WHO) }\end{array}$ & World Organisation for Animal Health (OIE) & $\begin{array}{l}\text { Food and Agriculture } \\
\text { Organization of the United } \\
\text { Nations(FAO) }\end{array}$ \\
\hline $\begin{array}{l}\text { The WHO global action plan sets out five } \\
\text { strategic objectives: }\end{array}$ & $\begin{array}{l}\text { The OlE Strategy supports the objectives } \\
\text { established in the Global Action Plan and }\end{array}$ & $\begin{array}{l}\text { To support the implementation } \\
\text { of Resolution 4/2015, the FAO }\end{array}$ \\
& $\begin{array}{l}\text { reflects the mandate of the OIE as described } \\
\text { in its Basic Texts and Strategic Plans. It has }\end{array}$ & $\begin{array}{l}\text { Action Plan on AMR (2016-2020) } \\
\text { addresses four major Focus }\end{array}$ \\
& four objectives: & Areas:
\end{tabular}

- To improve awareness and understanding of antimicrobial resistance:

- To strengthen knowledge through surveillance and research;

- To reduce the incidence of infection;

- To optimise the use of antimicrobial agents; and

- To develop the economic case for sustainable investment that takes account of the needs of all countries, and increase investment in new medicines, diagnostic tools, vaccines, and other interventions.
- Improve awareness and understanding

- Strengthen knowledge through surveillance and research

- Support good governance and capacity building

- Encourage implementation of international standards
- Improve awareness on AMR and related threats;

- Develop a capacity for surveillance and monitoring of AMR and AMU (antimicrobial use) in food and agriculture;

- Strengthen governance related to AMU and AMR in food and agriculture;

- Promote good practices in food and agricultural systems and the prudent use of antimicrobials. 
For $2 \mathrm{~b}$, in terms of bacterial pathogens, potential data sources at the country level may include the following: (1) a country's National Pathogen List, if this exists as part of a National Strategy on Aquatic Animal Health or Aquaculture Biosecurity; (2) disease information from diagnostic laboratories;
(3) quarantine records; (4) disease information from primary producers; (5) disease information published in the scientific and grey literature; and (6) national residue testing programme, if it exists. A compilation of a list of important bacterial pathogens in aquaculture production can be found in Table 2 below.

Table 2. List of important bacterial pathogens in aquaculture production (Bondad-Reantaso et al., 2020).

\begin{tabular}{|c|c|c|}
\hline According to & Pathogen & Reference \\
\hline $\begin{array}{l}\text { Responsible management of bacterial } \\
\text { diseases in aquaculture (in preparation) }\end{array}$ & & $\begin{array}{l}\text { FAO/HQ Aquaculture Biosecurity team } \\
\text { (Regional consultation on AMR } \\
\text { Monitoring and Surveillance Guidelines } \\
\text { Volume 3: "Monitoring and surveillance } \\
\text { of AMR in bacteria from aquaculture" }\end{array}$ \\
\hline Gram negative & $\begin{array}{l}\text { Vibriosis, Aeromonasis, Edwardsiellosis, } \\
\text { Pseudomonasis, Flavobacteriosis, Infection with } \\
\text { intracellular bacteria }\end{array}$ & \\
\hline Gram positive & $\begin{array}{l}\text { Mycobacteriosis, Streptococcosis, Renibacteriosis, } \\
\text { Infection with anaerobic bacteria }\end{array}$ & \\
\hline $\begin{array}{l}\text { Best practice guidelines for the } \\
\text { performance of bacterial susceptibility } \\
\text { tests }\end{array}$ & & Smith, 2019 \\
\hline Non-fastidious Gram-negative bacteria & $\begin{array}{l}\text { Aeromonas caviae, Aeromonas hydrophila, } \\
\text { Aeromonas jandaei, Aeromonas salmonicida, } \\
\text { Aeromonas sobria, Aeromonas veronii, Acinetobacter } \\
\text { spp. } \\
\text { Citrobacter freundi, } \\
\text { Edwardsiella anguillarum, Edwardsiella ictalurid, } \\
\text { Edwardsiella piscicida, Edwardsiella tarda, } \\
\text { Pseudomonas anguilliseptica, Pseudomonas } \\
\text { fluorescens, Yersinia ruckeri }\end{array}$ & \\
\hline $\begin{array}{l}\text { Halophilic Gram-negative bacteria } \\
\text { (facultative and obligate halophiles) }\end{array}$ & $\begin{array}{l}\text { Aliivibrio salmonicida, Photobacterium damselae, } \\
\text { Vibrio alginolyticus, Vibrio anguillarum, Vibrio harveyi, } \\
\text { Vibrio parahaemolyticus, Vibrio vulnificus }\end{array}$ & \\
\hline Flavobacteria and related species & $\begin{array}{l}\text { Flavobacterium branchiophilum, Flavobacterium } \\
\text { columnare, Flavobacterium psychrophilum, } \\
\text { Tenacibaculum maritimum }\end{array}$ & \\
\hline Gram-positive cocci & $\begin{array}{l}\text { Mesophilic species (Aerococcus viridans, } \\
\text { Lactococcus garvieae, Streptococcus agalactiae, } \\
\text { Streptococcus dysgalactiae, Streptococcus iniae, } \\
\text { Streptococcus phocae, Weissella spp., Psychrophilic } \\
\text { spp., Lactococcus piscium, Vagococcus } \\
\text { salmoninarum) }\end{array}$ & \\
\hline Mycobacteria and related species & $\begin{array}{l}\text { Mycobacterium fortuitum, Mycobacterium marinum, } \\
\text { Nocardia asteroids, Nocardia crassostreae, Nocardia } \\
\text { seriolae }\end{array}$ & \\
\hline NACA/FAO/OIE List & $\begin{array}{l}\text { Mollusc (Xenohaliotis californiensis) } \\
\text { Crustacean (Vibrio parahaemolyticus, Hepatobacter } \\
\text { penaei) }\end{array}$ & OlE, 2020 \\
\hline & $\begin{array}{l}\text { Finfish (Edwardsiella ictaluri) } \\
\text { Crustacean (Spiroplasma eriocheiris) }\end{array}$ & $\begin{array}{l}\text { NACA/FAO/OIE Quarterly Aquatic Animal } \\
\text { Disease Report }\end{array}$ \\
\hline Review papers & $\begin{array}{l}\text { Vibrio parahaemolyticus, Vibrio harveyi, Vibrio } \\
\text { alginolyticus, Vibrio campbellii, Spiroplasma penaei } \\
\text { Aeromonas spp., Edwardsiella spp., Flavobacterium } \\
\text { spp., Streptococccus spp., Lactococcus spp., Vibrio } \\
\text { spp., Yersinia spp. }\end{array}$ & $\begin{array}{l}\text { Morales-Covarrubias, } 2018 \\
\text { Reverter et al., } 2020\end{array}$ \\
\hline \multicolumn{3}{|l|}{ Country information } \\
\hline China & $\begin{array}{l}\text { Finfish (Aeromonas caviae, Aeromonas hydrophila, } \\
\text { Aeromonas sobria, Edwardsiella tarda, } \\
\text { Flavobacterium columnare, Pseudomonas } \\
\text { alcaligenes, Pseudomonas putida, Streptococcus } \\
\text { spp., Vibrio anguillarum, Yersinia ruckeri } \\
\text { Crustaceans (Vibrio anguillarum, Vibrio harveyi, Vibrio } \\
\text { parahemolyticus) } \\
\text { Mollusc (Aeromonas hydrophila, Vibrio alginolyticus, } \\
\text { Vibrio flucialis } I I \text { ) }\end{array}$ & $\begin{array}{l}2019 \text { National Surveillance - National } \\
\text { Pathogen List }\end{array}$ \\
\hline & $\begin{array}{l}\text { Campylobacter, Enterococcus faecalis, Escherichia } \\
\text { coli, Salmonella, Staphylococcus aureus }\end{array}$ & NAP on AMR \\
\hline Malaysia & $\begin{array}{l}\text { Aeromonas salmonicida, Streptococcus } \\
\text { Vibrio parahaemolyticus, Escherichia coli }\end{array}$ & $\begin{array}{l}\text { National Pathogen List } \\
\text { NAP on AMR }\end{array}$ \\
\hline Viet Nam & Streptococcus spp., Aeromonas hydrophila & \\
\hline
\end{tabular}


This list was compiled by Bondad-Reantaso et al. (2020) from several sources including the following:

- Responsible management of bacterial diseases in aquaculture, a publication in preparation, contains six groups of Gram-negative bacteria (Vibriosis, Aeromonasis, Edwardsiellosis, Pseudomonasis, Flavobacteriosis, Infection with intracellular bacteria) and four groups of Gram-positive bacteria (Mycobacteriosis, Streptococcosis, Renibacteriosis, Infection with anaerobic bacteria.

- Best practice guidelines for the performance of bacterial susceptibility tests: this publication (Smith 2019) contains a list of bacteria isolated from aquatic animals or aquatic environment categorised as: Non-fastidious Gram-negative bacteria; Halophilic Gram-negative bacteria (facultative and obligate halophiles); Flavobacteria and related species; Grampositive cocci; and Mycobacteria and related species.

- NACA/FAO/OIE lists: bacterial pathogens affecting finfish, molluscs, and crustaceans. There are only three pathogens in the OIE list and five in the NACA/FAO/OIE regional list of diseases that is part of the Quarterly Aquatic Animal Disease reporting system.

- Review papers: two review papers: (1) bacterial diseases of farmed shrimp in Latin American countries (Morales-Covarrubias, 2018) and (2) major bacterial pathogens in aquaculture (Reverter et al., 2020).

- Country information: bacterial pathogens of concern can be part of a surveillance programme, national pathogen list, or NAP on AMR.

For 2c, there are existing guidance documents on maximum residue limit (MRL) for fish products. The $M R L$ is the maximum concentration of residue legally tolerated in a food product obtained from an animal that has received a veterinary medicine (FAO, 2018). Information on $2 \mathrm{c}$ is needed for $2 \mathrm{~d}$ and $2 \mathrm{e}$.

After identification of the farmed species and bacterial pathogens of concern, the next step is to understand how these disease problems are being addressed which may include any or a combination of the following measures, such as prevention, good aquaculture/biosecurity practices, treatment with antibiotics, alternative treatment.

For $2 d$, information can be generated from a country's Competent Authority responsible for the management and control of diseases in the aquaculture sector, as well as from the industry and academic and research stakeholders.
Items $2 \mathrm{~d}$ and $2 \mathrm{e}$ are interrelated in the sense that if bacterial diseases are being addressed through the use of antibiotics, then the next step will be to understand AMU especially antibiotics. The specific guidance in the collection of information on AMU and AMR can be found in Bondad-Reantaso et al. (2020). The guidance consists of nine sections, namely: Section 1 (Contact person profile); Section 2 (Farm information); Section 3 (Types of antimicrobial agents used in cultured species in terms of treatment, prevention, disinfection, or other uses); Section 4 (Doses of antimicrobial agents used in cultured species, expressed in $\mathrm{mg}$ ); Section 5 (Duration of antimicrobial agents used in cultured species, expressed in days); Section 6 (Effectiveness of antimicrobial agents used in cultured species, expressed in percent; Section 7 (In your experience, what is the availability of these agents, in terms of: freely available in the market, through prescription, no information?; Section 8 (Drug sales); and Section 9 (Drug sales by routes of administration, e.g. medicated feed; bath treatment; directly to the pond; parenteral delivery). In addition to the suggested forms to be filled up, guidance notes were also provided on the following aspects: collection of data; logistics/operational aspects, stakeholders, surveillance objectives, sampling design, target microorganisms, and laboratory methodology.

Item $2 f$ is also an essential step. Surveillance is an economic activity and thus it is essential to identify requirements for AMU and AMR surveillance (personnel, field/laboratory procedures, skills, facilities, policies/legislation, reporting/record keeping, monitoring, etc.).

Other essential and relevant guidance that can be used include the following:

- OIE International Standards on Responsible and Prudent Use of Antimicrobials: Use of antimicrobial agents in aquatic animals (2020a).

The relevant chapters are:

a) Chapter 6.1: Introduction to the recommendations for controlling AMR

b) Chapter 6.2 Principles for responsible and prudent use of antimicrobial agents in aquatic animals

c) Chapter 6.3 Monitoring the quantities and usage patterns of antimicrobial agents used in aquatic animals

d) Chapter $6.4 \quad$ Development and harmonization of national AMR surveillance and monitoring programmes for aquatic animals

e) Chapter 6.5 Risk analysis for AMR arising from the use of antimicrobial agents in aquatic animals. 
- Antimicrobial susceptibility testing programmes. This technical paper (Smith, 2019) addresses best practice guidelines for the performance of antimicrobial susceptibility testing of bacteria isolated from aquatic animals as part of a monitoring or surveillance programme or to provide guidance for clinical treatments of diseased animals. It contains six sections, namely: Section 1: Relevance of the document to the Action Plan; Section 2: Principles of antimicrobial susceptibility testing; Section 3: Standard protocols recommended for use in antimicrobial susceptibility testing of bacteria isolated from aquatic animals; Section 4: Design of programmes aimed at monitoring or surveillance of AMR associated with the use of antimicrobial agents in the rearing of aquatic animals; Section 5: Conclusions; and Section 6: References.

- FAO Code of Conduct for Responsible Fisheries: Aquaculture development. 8. Recommendations for prudent and responsible use of veterinary medicines in aquaculture. These Technical Guidelines (FAO, 2019) are developed to support Section 9 - Aquaculture Development of FAO's CCRF (No. 5, Suppl. 8) and The FAO Action Plan on Antimicrobial Resistance 2016-2020. They also support the international aquatic animal health standards of the OIE, food safety standards of the FAO/WHO Codex Alimentarius, and the One Health platform under the FAO/OIE/WHO Tripartite Collaboration on AMR. Their objective is to assist countries in encouraging the prudent and responsible use of veterinary medicines (antimicrobial agents and other chemotherapeutants) in aquaculture production through appropriate government regulation and the promotion and encouragement of awareness and responsible use by the concerned government agencies, private-sector aquaculture producers, and aquatic animal health professionals. They emphasise, among the guiding principles, that responsible use of veterinary medicines in aquaculture requires collaboration among all stakeholders and a strong commitment to governance, awareness, best practices, surveillance, and research, including monitoring of $A M R$, tracking of antimicrobial usage (AMU), assessing risk in different settings and evaluating strategies to reduce AMR and maintain the efficacy of antimicrobial agents.

Once the specific guidance in understanding the aquaculture sector are put in place, the next step will be to look at the other relevant objectives, in terms of awareness, knowledge generation, and capacity development as in Table 1 that can be a useful reference. The aquaculture component will need to be integrated in the country's overall AMR NAP and within the One Health approach/framework.

\section{Conclusion}

The important role played by aquaculture in providing high-quality nutrition, improving livelihoods, stimulating and creating decent work and economic growth, and alleviating poverty, particularly in lowincome food-deficit countries and the need to address biosecurity, one of the most important sustainability challenges, can be important drivers for supporting AMR stewardship.

The preliminary guidance (generic and specific) in the development of the aquaculture component of a country's NAP on AMR are important first steps in the process. Having such a plan will now allow the responsible Competent Authority to raise the profile of aquaculture in national discourses on AMR, generate an understanding of the sector and its importance by other relevant sectors engaged in the One Health platform, stimulate investment and support towards further development and implementation of the action plan. The aquaculture component needs to be fully integrated in a country's NAP on AMR.

These guidelines were used, to a certain extent, by participating countries (e.g. China, Malaysia, the Philippines and Viet Nam) in the mentioned FAO project FMM/RAS/298/MUL. The example set by these countries shows that the guidance can be a straightforward method from which national strategies on AMR can build upon.

There is an urgent need for aquaculture countries, especially those with substantial aquaculture production and food security objectives through aquaculture, to pay high attention to the emergence of antimicrobial-resistant organisms that can result from antimicrobial imprudent and irresponsible use in the aquaculture sector.

\section{References}

Bondad-Reantaso, M.G., C. R. Lavilla-Pitogo, Karunasagar, I., Arthur, J.R., Hao, B., Irde, E., GarridoGamarro, E. Peñarubia, O.R. 2020. Outputs and activities of FAO Project FMM/RAS/298/MUL on antimicrobial resistance in fisheries and summary of FAO's recent work on antimicrobial resistance in aquaculture. FAO Fisheries and Aquaculture Circular No. 1215. FAO, Rome. https://doi.org /10.4060/cb1209en

FAO. 2016. The FAO Action Plan on Antimicrobial Resistance 20162020: Supporting the food and agriculture sectors in implementing the Global Action Plan on Antimicrobial Resistance to minimize the impact of antimicrobial resistance. Rome, Italy. http://www.fao.org 3/a-i5996e.pdf (Accessed 25 May 2020).

FAO. 2017. FAO Project FMM/RAS/298/MUL: Strengthening capacities, policies and national action plans on prudent and responsible use of antimicrobials in fisheries: Final Workshop, Concorde Hotel, Singapore, 12-14 December 2017. Food and Agriculture Organization. 
http://www.fao.org/fi/static-media/MeetingDocuments

WorkshopAMR17/List.html (Accessed 26 May 2020).

FAO. 2018. Codex Alimentarius: Codex Texts - Maximum Residue Limits (MRLs). http://www.fao.org/fao-who-codexalimentarius/codextexts/maximum-residue-limits/en/(Accessed 28 November 2020).

FAO. 2019. Aquaculture development. 8. Recommendations for prudent and responsible use of veterinary medicines in aquaculture. FAO Technical Guidelines for Responsible Fisheries. No. 5. Suppl. 8. FAO, Rome. http://www.fao.org/documents/card/en/c/ca7029en/ (Accessed 26 November 2020).

FAO. 2020. Second Consultation Meeting on Regional AMR Monitoring and Surveillance Guidelines Volume 3: "Monitoring and surveillance of AMR in aquaculture". 22-26 June 2020, Bangkok/Singapore. http://www.fao.org/3/cb1377en/cb1377en.pdf $\quad$ (Accessed 28 November 2020).

Morales-Covarrubias, M.S., Cuellar-Anjel, J., Varela-MejTas, A. Elizondo-Ovares, C., 2018. Shrimp bacterial infections in Latin America: A review. Asian Fisheries Science 31S:7687. https://doi.org/10.33997/j.afs.2018.31.S1.005

Network of Aquaculture Centres in Asia-Pacific (NACA), World Organisation for Animal Health (OIE) Regional Representation for Asia and the Pacific, Food and Agriculture Organization of the United Nations (FAO). 2020. Quarterly Aquatic Animal Disease Report (Asia and Pacific Region), 2019/4, October-December 2019. NACA Bangkok, Thailand and OIE-RRAP, Tokyo, Japan. https://enaca.org/?id=1106\&title=quarterly-aquatic-animal-diseasereport-october-december-2019 (Accessed 28 November 2020).

OIE. 2016. The OIE Strategy on Antimicrobial Resistance and the Prudent Use of Antimicrobials. https://www.oie.int/fileadmin/Home leng/Media_Center/docs/pdf/PortailAMR/EN_OIE-AMRstrategy.pdf (Accessed 28 November 2020).

OIE. 2020a. Aquatic Animals Commission and reports: Responsible and prudent use of antimicrobials. https://www.oie.int/en/standardsetting/specialists-commissions-working-ad-hoc-groups/aquaticanimals-commission-reports/responsible-and-prudent-use-ofantimicrobial-agents/(Accessed 28 November 2020).

OIE. 2020b. OIE-Listed diseases, infections, and infestations in force in 2020. https://www.oie.int/animal-health-in-the-world/oie-listeddiseases-2020/(Accessed 28 November 2020).

Reverter, M., Sarter, S., Caruso, D., Avarre, J.C., Combe, M., Pepey, E., Pouyaud, L., Vega-Heredia, S., De Verdal, H., Gozlan, R.E. 2020. Aquaculture at the crossroads of global warming and antimicrobial resistance. Nature Communications 11:1-8. https://doi.org/10.1038/s41467-020-15735-6

Smith, P. 2019. The performance of antimicrobial susceptibility testing programmes relevant to aquaculture and aquaculture products. FAO Fisheries and Aquaculture Circular No. 1191. FAO, Rome. http://www.fao.org/documents/card/en/c/ca6028en/

WHO. 2015. Global Action Plan on Antimicrobial Resistance. Geneva Switzerland. https://www.who.int/antimicrobial-resistance /publications/global-action-plan/en/(Accessed 25 May 2020). 